\title{
SISTEM INFORMASI PELAYANAN PASIEN STUDI KASUS KLINIK JATI HUSADA TANGERANG
}

\author{
Arief Herdiansah*1, Nora Fitriawati ${ }^{2}$, Achmad Hariri ${ }^{3}$ \\ ${ }^{1,3}$ Prodi Teknik Informatika, Universitas Muhammadiyah Tangerang \\ ${ }^{2}$ Prodi Teknik Informatika, Universitas Bina Nusantara \\ Email: 1arief_herdiansah@umt.ac.id, ${ }^{2}$ nora.fitriawati@binus.edu, ${ }^{3}$ hariri.umt@gmail.com \\ *Penulis Korespondensi
}

(Naskah masuk: 21 Nopember 2019, diterima untuk diterbitkan: 11 Juni 2021)

\begin{abstract}
Abstrak
Klinik Jati Husada merupakan sebuah klinik di Kabupaten Tangerang, dimana saat ini proses pendataan pasien dan rekam medis pasien masih dilakukan secara manual. Dokter yang bertugas di klinik tersebut melakukan pencatatan rekam medis pasien pada buku pasien. Berdasarkan informasi awal yang didapatkan, admin klinik Husada Tangerang mengalami beberapa kesulitan antara lain: kesulitan dalam mengelola buku rekam medis pasien yang jumlahnya dari hari ke hari semakin banyak, kesulitan mencari kembali buku rekam medis pasien dan kesulitan penyimpanan buku rekam medis. Saat pihak klinik menyimpan buku rekam medis di lantai dua klinik tersebut sehingga memerlukan effort cukup besar pada saat pengambilan kembali buku rekam medis pasien. Dari sisi pasien juga seringkali harus menunggu lama untuk dapat masuk ke ruang pemeriksaan dokter karena menunggu buku rekam medis yang sedang diambil petugas klinik. Untuk meningkatkan efisiensi dan efektifitas serta menjaga keutuhan data rekam medis pasien, peneliti melakukan penelitian di klinik Jati Husada Tangerang. Penelitian ini merupakan penelitian terapan dimana menggunakan metode pengumpulan data kualitatif dan kuantitatif. peneliti menggunakan UMLdalam membuat pemodelan desain OOP untuk sistem yang dikembangkan. Proses pembangunan sistem dalam penelitian ini menggunakan model pengembangan sistem waterfall dan bahasa pemrograman PHP. Sistem yang dihasilkan telah diuji dan diimplementasikan. Sistem yang dihasilkan telah dapat membantu petugas klinik dalam mengelola rekam medis, membantu dokter untuk lebih cepat mengetahui data mengelola rekam medis pasien, data obat, data dokter sehingga dapat meningkatkan pelayanan klinik bagi pasien. Peneliti berharap sistem pelayanan pasien yang dibangun ini dapat menjadi referensi bagi klinik pengobatan ditempat lain yang sejenis.
\end{abstract}

Kata kunci: Sistem Informasi, Pelayanan, Pasien, Klinik, Rekam medis

\section{INFORMATION SYSTEM FOR PATIENT SERVICE CASE STUDY AT JATI HUSADA CLINIC TANGERANG}

\begin{abstract}
Jati Husada Clinic is a clinic in Tangerang, currently the patient data collection process and patient medical records are still recorded manually. The doctor on duty at the clinic records the patient's medical records in the patient book. Based on preliminary information, the Husada Tangerang clinic admin is experiencing several difficulties, including: difficulty in managing the increasing number of patient medical record books, difficulty finding patient medical record books again and difficulties in storing medical record books. When the clinic keeps a medical record book on the second floor of the clinic, it requires considerable effort when retrieving the patient's medical record book. From the patient's side, he often has to wait a long time to get into the doctor's examination room because he is waiting for the medical record book that is being taken by the clinic staff. To increase efficiency and effectiveness and maintain the completeness of patient medical record data, researchers conducted research at the Jati Husada clinic in Tangerang. This research is an applied research which uses qualitative and quantitative data collection methods. Researchers use UML in making OOP design modeling for the system being developed. The system development process in this study uses the waterfall system development model and the PHP programming language. The resulting system has been tested and implemented. The resulting system has been able to assist clinical officers in managing medical records, helping doctors to more quickly find out data about managing patient medical records, drug data, doctor data so as to improve clinical services for patients. Researchers hope that this patient service system built can be a reference for similar medical clinics in other places.
\end{abstract}

Keywords: Information Systems, Services, Patients, Clinics, Medical record 


\section{PENDAHULUAN}

Klinik menjadi tempat alternatif untuk berobat, banyak orang yang memilih berobat ke klinik dari pada harus berobat ke Rumah Sakit dengan berbagai macam alasan, antara lain lokasi yang lebih dekat dengan rumah dan biaya yang lebih terjangkau. Dengan banyaknya pasien yang berdatangan, dibutuhkan sebuah sistem pelayanan pasien yang terkomputerisasi sehingga dapat memudahkan petugas klink dalam melakukan berbagai aktifitas pelayanan pasien. Implementasi informasi dan komunikasi teknologi dalam perawatan kesehatan semakin menunjukkan keseriusan dalam mendukung pemberian perawatan kesehatan, meningkatkan kesehatan, efisiensi layanan dan memberikan terbaik bagi pasien (Pan et al., 2016) (Fu and Ling, 2014).

Klinik Jati Husada Tangerang merupakan salah satu klinik umum yang setiap hari selalu dipenuhi pasien. Proses pelayanan di klinik Jati Husada Tangerang saat ini masih dilakukan dengan manual mulai dari pendaftaran sampai dengan pencatatan pencatatan rekam medis pasien. Dari hasil pengumpulan data dengan metode observasi, wawancara dan survey, didapat informasi bahwa saat ini klinik Jati Husada memiliki permasalahan dikarenakan proses pencatatan rekam medis pasien masih dilakukan secara manual, dimana permasalahan yang saat ini ada antara lain:

1. Staf klinik mengalami kesulitan dalam mengelola buku rekam medis pasien yang jumlahnya dari hari ke hari semakin banyak.

2. Staf klinik mengalami kesulitan mencari kembali buku rekam medis pasien yang dibutuhkan.

3. Klinik mengalami kesulitan menyimpanan buku rekam medis, karena semakin lama dibutuhkan area penyimpanan buku rekam medis yang semakin besar sehingga saat ini pihak klinik menyimpan buku rekam medis di lantai dua klinik tersebut.

4. Pelayanan kepada pasien terganggu karena pasien harus menunggu cukup lama untuk dapat masuk ke ruang periksa dokter karena menunggu buku rekam medis pasien tersebut tersedia.

5. Jika seorang dokter ingin mempelajari data kesehatan pasien rekam medis yang telah diobati sebelumnya, dokter harus menunggu staf klinik mengambilkan buku rekam medis pasien tersebut.

Kelima permasalahan diatas berakibat pada kurang maksimalnya pelayanan yang diberikan klinik Jati Husada pada pasien.

Berdasarkan kondisi diatas, peneliti mencoba memberikan sebuah solusi yang dapat meningkatkan pelayanan di klinik Jati husada Tangerang dengan cara mengembangkan sebuah sistem informasi pelayanan pasien. Peneliti menggunakan metode pengumpulan data kualitatif dan kuantitatif, dengan melakukan aktifitas observasi, wawancara dan penyebaran form survey kepada beberapa pasien untuk mengetahui kendala yang ada dan untuk mencari solusi dalam bentuk sebuah sistem informasi untuk menyelesaikan terhadap permasalahan tersebut. Peneliti menggunakan UML (Unified Modeling Language) dalam membuat pemodelan desain program berorientasi objek (OOP) dari sistem yang dikembangkan, sedangkan proses pembangunan sistem menggunakan model pengembangan sistem waterfall dengan menggunakan bahasa pemrograman PHP. Metode pengujian sistem yang digunakan dalam penelitian ini adalah black box testing dimana peneliti menguji setiap modul yang tersedia di sistem yang dikembangkan bersama-sama pengguna dan peneliti telah memperbaiki semua modul yang dirasa kurang sesuai dengan permintaan pengguna.

Sistem pengolahan data administrasi merupakan salah satu kegiatan yang selalu ada dalam sebuah kegiatan organisasi (Herliana, 2014). Sedangkan sistem informasi merupakan disiplin yang belum sepenuhnya mapan seperti matematikan dan ekonomi sehingga diperlukan pengetahuan serta pemahaman mengenai ruang lingkup kajian bidang ilmu sistem informasi, dengan demikian diharapkan pengetahuan tersebut dapat memberikan perspektif yang jauh lebih luas dalam memandang posisi antara disiplin sistem informasi dibandingkan dengan disiplin ilmu yang lain (Sudaryono, 2015). Manajemen sistem informasi yang baik berhubungan erat dengan pengolahan data yang baik, jika pengolahan data masih belum terkomputerisasi dengan baik akan mengakibatkan kualitas informasi yang dihasilkan kurang akurat (Fitrawati, Herdiansah and Gunawan, 2019).

Dalam sebuah proses pengembangan sistem yang paling utama yaitu proses analisis, proses desain dan proses implementasi sistem (Jogiyanto, 2010). Sistem dan sistem informasi merupakan suatu hal yang saling berhubungan anatara satu dan lainnya yang pada akhirnya menghasilkan informasi atau data (Herdiansah, 2020). Kumpulan data dapat dikatakan informasi jika kumpulan data tersebut menghasilkan sebuah nilai guna bagi orang yang menerima kumpulan data tersebut atau dengan kata lain sesuai dengan peruntukannya.

Klinik juga mempunyai kewajiban mengelola data pasien, khususnya rekam medis pasien. Adanya berbagai tujuan dan fungsionalitas yang diharapkan dari suatu berkas termasuk rekam medis, mis. penyimpanan, presentasi, interaksi pengguna, dan digitalisasi, seringkali diperlukan model dan sistem data yang berbeda (Meyer, Finger and Heuer, 2015).

Penelitian yang dilakukan diharapkan menghasilkan sebuah sistem komputerisasi pengelolaan data rekam medis pasien selain itu juga dapat mengelola data obat, mengelola data dokter sehingga sehingga dapat meningkatkan pelayanan di klinik Jati Husada Tangerang, dimana sistem tersebut telah teruji menggunakan metode pengujian black box. 


\section{METODE PENELITIAN}

Metode penelitian kualitatif merupakan suatu metode baru dimana dalam proses penelitiannya kurang terpola karena data yang dihasilkan penelitian lebih berkenaan pada hasil interprestasi dari data yang ditemukan dilapangan, sedangkan metode kuantitaif merupakan metode penelitian dengan melakukan survei dan eksperimen dalam melakukan proses penelitian untuk mengetahui kebutuhan pengguna (Sugiyono, 2013).

Model pengembangan sistem menggunakan model watefall, merupakan sebuah metode pengembangan perangkat lunak (software) yang dilakukan secara berurutan, terstruktur dan berjalan ke bawah layaknya sebuah air terjun, dimana melewati beberapa tahapan mulai dari perencanaan, pemodelan, implementasi sampai dengan pengujian (Pressman, 2015). Metode waterfall, merupakan metode yang banyak digunakan oleh para pengembang sistem informasi karena sifatnya terstruktur dan mudah dipahami sebagai sebuah siklus hidup klasik (classic life cycle) pengembangan sebuah sistem informasi (Herdiansah, Rosdiana and Wulandani, 2019).

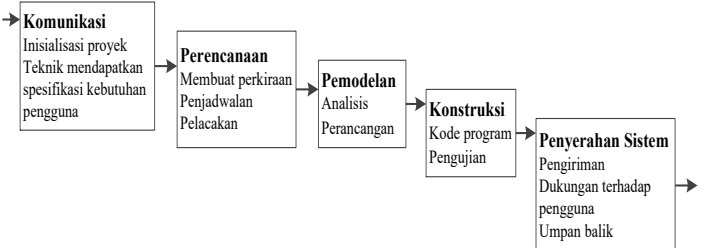

Gambar 1. Model Waterfall (PRESSMAN, 2015)

\section{A. Tahap Komunikasi}

Dalam tahap ini oeneliti melakukan wawancara secara langsung kepada petugas dan pimpinan klinik dan melakukan opservasi.

Metodologi pengumpulan data yang dilakukan digunakan dalam penelitian ini adalah metode kualitatif dan kuantitatif dimana peneliti mengumpulkan data dari hasil aktifitas wawancara, catatan hasil observasi, dokumen pribadi, catatan/memo dan data rekapitulasi kunjungan pasien di klinik Jati Husada.

Metode pengumpulan data yang digunakan dalam penelitian ini antara lain:

\section{1) Wawancara}

Wawancara merupakan teknik pengumpulan data yang dilakukan melalui wawancara penulis dengan narasumber berdasarkan waktu yang telah disepakati terlebih dahulu. Pada proses wawancara, peneliti mengajukan beberapa pertanyaan yaitu

a) Pada hari apa saja dan jam berapa klinik ini buka praktek?

b) Ada berapa total karyawan yang bekerja di klinik ini ?

c) Bagaimana jika sistem pelayanan pasien seperti pencatatan data pasien, data periksa pasien hingga pelaporan menggunakan sistem komputerisasi?

d) Apa harapan terhadap sistem ini ?

\section{2) Observasi}

Teknik observasi yang peneliti lakukan adalah observasi berstruktur yaitu dengan menyiapkan daftar kebutuhan dan sumber data berkaitan penelitian yang peneliti lakukan. Proses observasi dilakukan untuk mempelajari data-data dari hasil kegiatan yang dilakukan dan dokumen arsip klinik, antara lain mengamati semua dokumen yang berhubungan dengan sistem pendaftaran pasien dan arsip resep yang diberikan dokter klinik, sebagaimana Gambar 1 dan Gambar 2 dibawah ini:
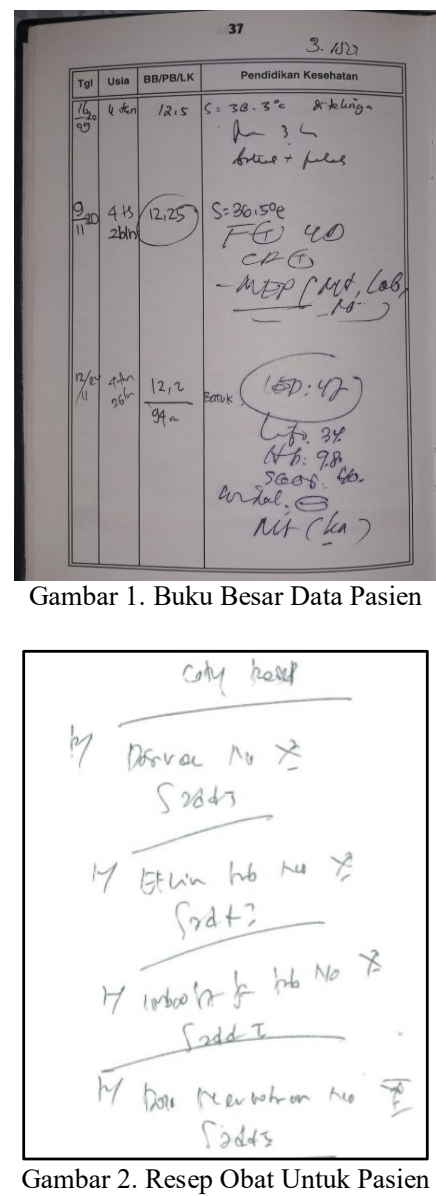

B. Perencanaan

Pada tahap ini peneliti membuat penjadwalan penyembangan sistem.

C. Pemodelan

Pada tahap ini peneliti membuat perancangan sistem informasi pelayanan pasien menggunakam UML.

\section{Konstruksi}

Pada tahap ini peneliti membangun aplikasi menggunakan Bahasa pemrograman PHP dan MySQL database.

\section{E. Penyerahan Sistem}

Tahap ini merupakan tahapan implementasi kepada klinik, dimulai dengan instalasi, kemudian pengujian sistem dan kemudian . 


\section{HASIL DAN PEMBAHASAN}

\section{A. Hasil Komunikasi Pengumpulan Data}

Klinik Jati Husada Tangerang buka setiap hari mulai pukul $08.00 \mathrm{~s} / \mathrm{d} 22.00$ dengan jumlah karwawan 7 orang dan 2 dokter. Saat ini proses administrasi pelayanan pasien masih dilakukan dengan pencatatan manual, sehingga dirasa perlu dikembangkan sistem informasi yang dapat mengingkatkan pelayanan kepada pasien.

B. Perencanaan Sistem

Peneliti merencanakan dapat melakukan perancangan dan pengembangan sistem dalam kurun waktu 6 minggu.

Minggu I : Pengumpulan data.

Minggu II : Buat draft perancangan sistem.

Minggu III : Finalisasi perancangan sistem

Minggu IV : Pembuatan Aplikasi (coding)

Minggu VI : Pengujian dan penyerahan sistem

\section{Pemodelan dan Perancangan Sistem}

\section{Gambaran Umum Sistem}

Sistem pelayanan pasien yang dikembangkan dapat dilihat pada Gambar 3 use case dibawah ini:

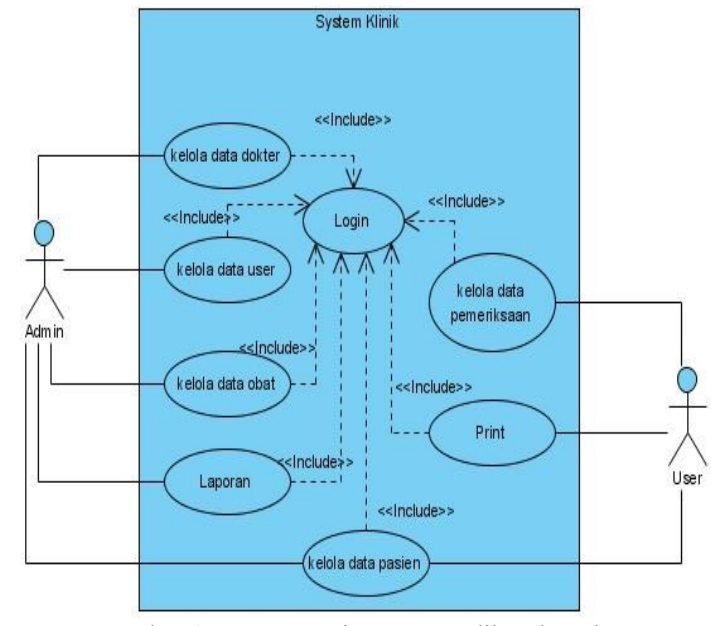

Gambar 3. Use Case sistem yang dikembangkan

Deskripsi use case yang diusulkan adalah sebagaimana tabel 1 penjelasan use case berikut:

Tabel 1. Penjelasan Use Case

\begin{tabular}{ccl}
\hline No & Aktor & \multicolumn{1}{c}{ Penjelasan } \\
\hline $1 \quad$ Admin & $\begin{array}{l}\text { Merupakan pengguna sistem yang memiliki } \\
\text { hak akses melakukan kelola data } \text { user, kelola } \\
\text { data dokter, kelola data obat, kelola data } \\
\text { pasien dan setting jenis laporan yang dapat } \\
\text { dihasilkan } \text { user. }\end{array}$ \\
& User $\quad \begin{array}{l}\text { Merupakan pengguna sistem yang memiliki } \\
\text { hak akses melakukan kelola data pasien (add, } \\
\text { edit dan delete data kunjungan pasien), kelola } \\
\text { data pemeriksaan (medical record) dan } \\
\text { melakukan pencarian data, serta pencetakan } \\
\text { laporan sesuai yang diinginkan. }\end{array}$ \\
\hline
\end{tabular}

\section{Activity Diagram}

Activity Diagram merupakan diagram yang menggambarkan aktivitas sebuah sistem.
a.Activity Diagram Login

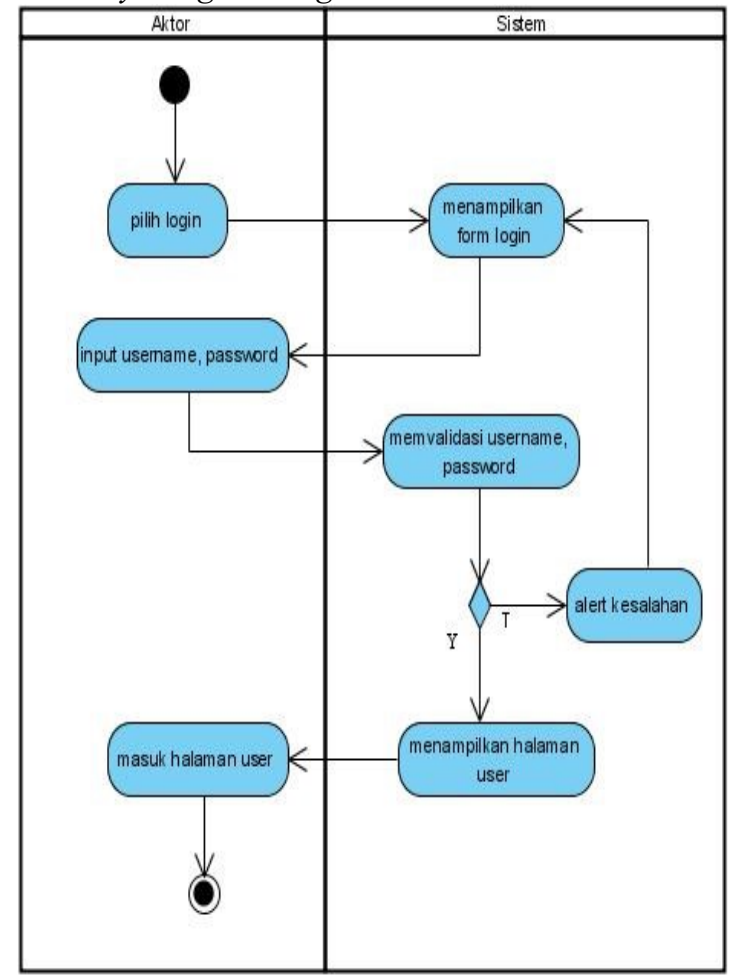

Gambar 4. Activity Diagram Login

b.Activity Diagram Kelola Data Pasien

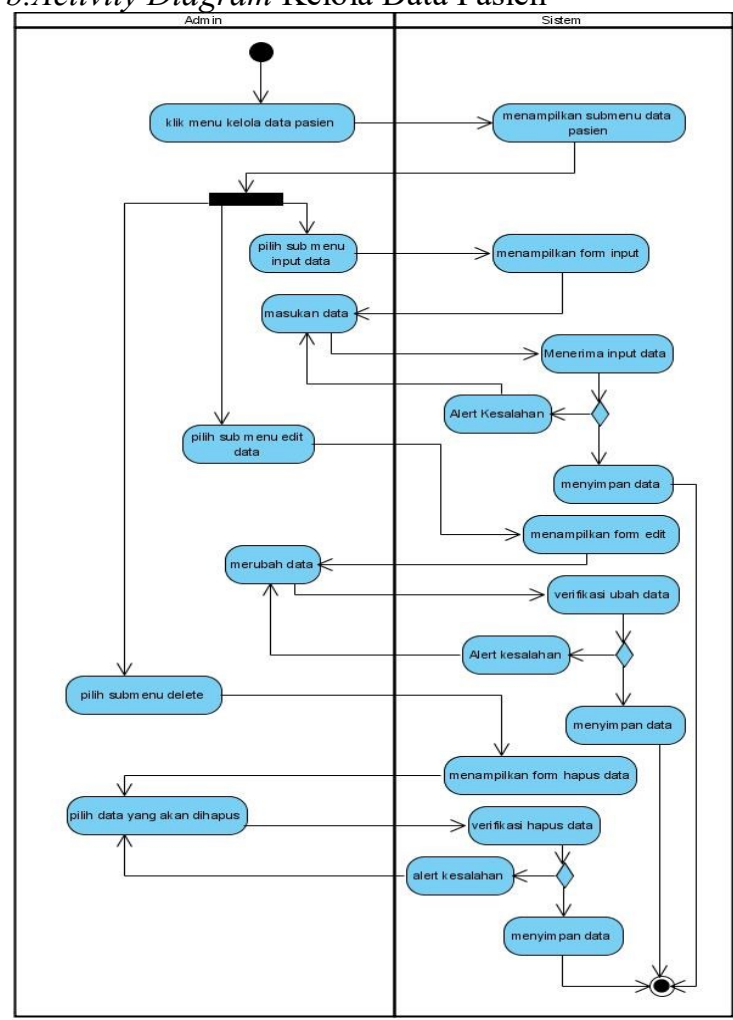

Gambar 5. Activity Diagram Kelola Data Pasien

\section{Class Diagram}

Class diagram sistem yang dibangun dapat dilihat pada gambar berikut ini: 


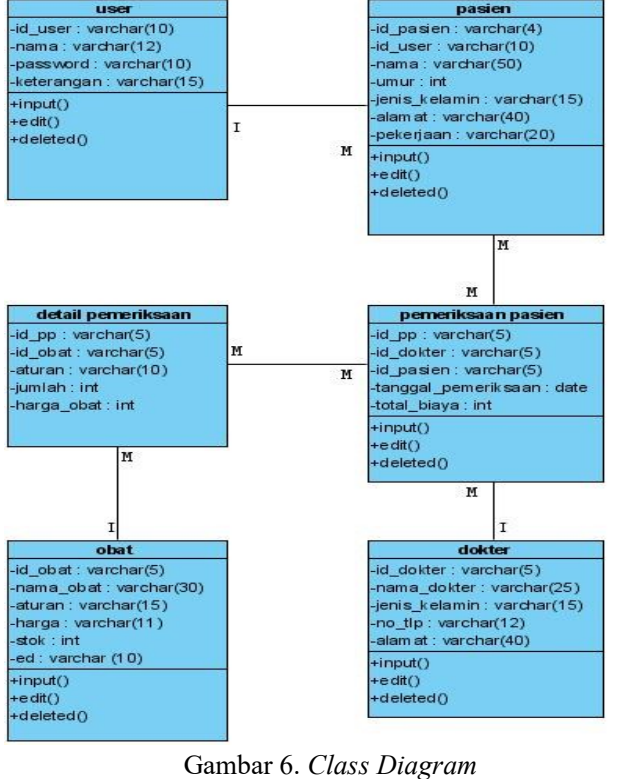

D. Pembangunan Sistem Informasi

Sistem informasi pelayanan pasien dibangun menggunakan Bahasa pemrogram PHP dan database MySQL. Hasil pengambangan system tersebut menghasilkan tampilan sebagai berikut:

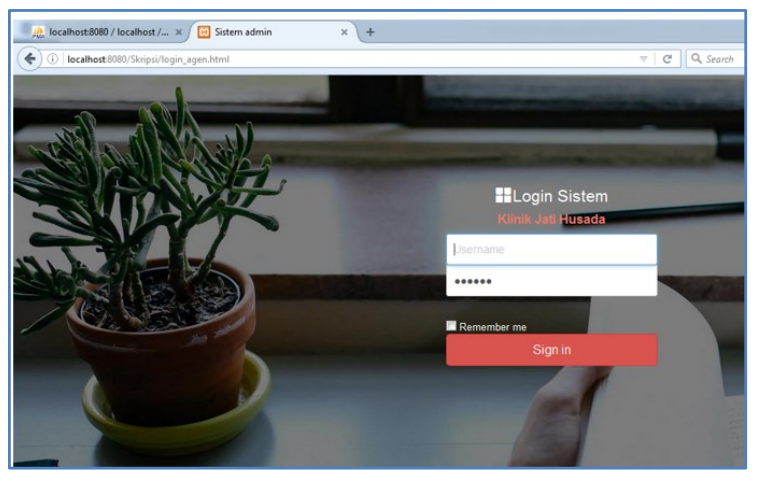

Gambar 7. Menu Login

Gambar 7 merupakan tampilan antar muka dari mеnu login sistem informasi pelayanan pasien yang dikembangkan, pada menu ini pengguna diminta untuk memasukan user name dan password agar dapat masuk dan mengakses semua modul yang ada.

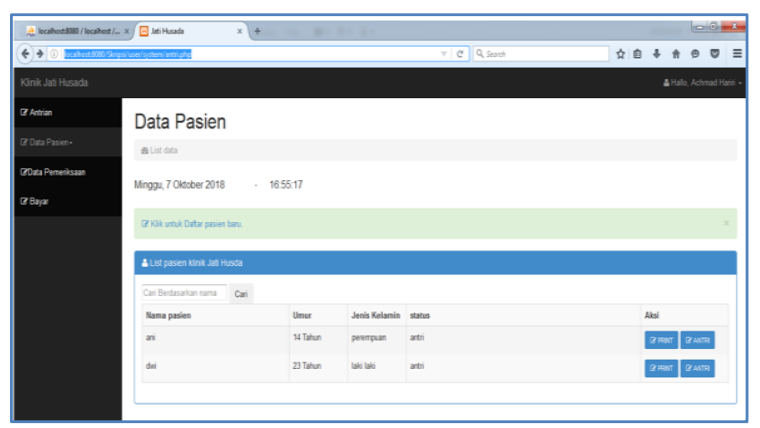

Gambar 8. Мепи Data Pasien

Gambar 8_merupakan tampilan antar muka dari menu pengelolaan data pasien (add, edit, delete). Pada menu ini pengguna dapat melihat seluruh biodata pasien yang pernah mendaftarkan diri dan berobat ke klinik. Menu ini memungkinkan proses pendaftaran kunjungan pasien menjadi lebih cepat serta pengelolaan data kunjungan menjadi lebih efektif dan efisien.

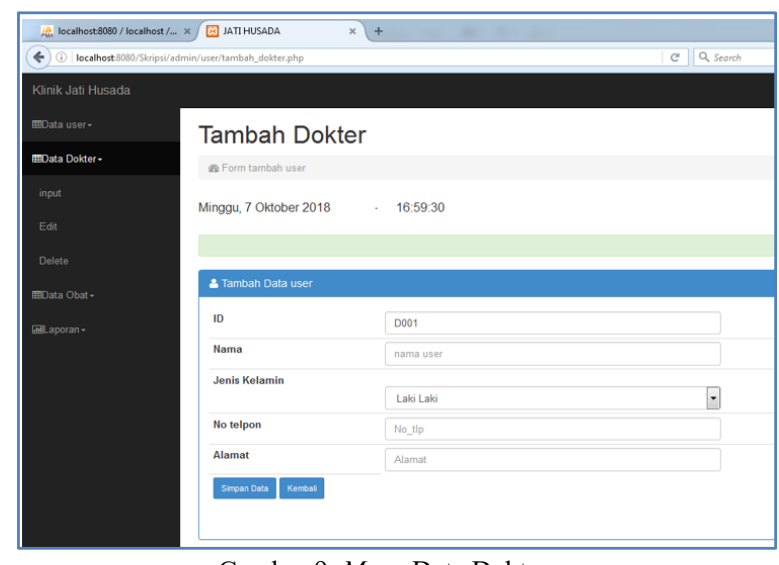

Gambar 9. Menu Data Dokter

Gambar 9 merupakan tampilan antar muka dari menu pengelolaan data dokter (add, edit, delete). Pada menu ini pengguna dapat melihat seluruh biodata dokter yang melakukan praktek di klinik.

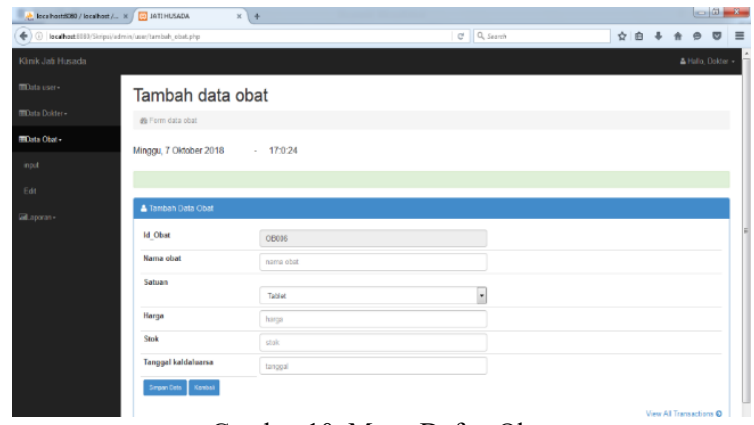

Gambar 10. Menu Daftar Obat

Gambar 10 merupakan tampilan antar muka dari menu daftar obat, pada menu ini pengguna dapat melakukan pengelolaan data obat (add, edit, delete). Data yang dapat dimasukan mulai dari kode obat, nama obat, harga obat, stok obat dan kadarluarsa obat tersebut, hal ini membuat proses pengelolaan data obat menjadi lebih efektif dan efisien dibandingkan proses pengelolaan sebelumnya.

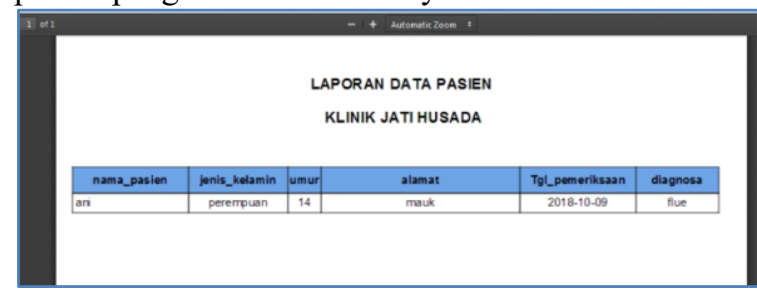

Gambar 11. Tampilan Laporan Data Pasien

Gambar 11 merupakan tampilan antar muka dari salah satu laporan yang dihasilkan sistem, pada gambar tersebut terlihat lakporan data searang pasien., dimana dapat 
kita lihat ada informasi berkaitan dengan nama pasien, jenis kelamin, umur, alamat tempat tinggal, tanggal pemeriksaan pasien dan hasil diagnose dokter pada pasien pada tanggal tersebut. Laporan yang dihasilkan ini telah dapat menggantikan laporan manual yang sebelumnya dibuat oleh petugas klinik.

\section{E. Pengujian Sistem}

Tabel 2 dibawah ini merupakan hasil pengujian sistem menggunakan metode Black Box.

Tabel 2. Hasil Pengujian Black Box

\begin{tabular}{|c|c|c|c|c|c|}
\hline No & Pengujian & Skenario Pengujian & $\begin{array}{c}\text { Detail } \\
\text { Pengujian }\end{array}$ & Hasil pengujian & Hasil Pengujian \\
\hline 1 & $\begin{array}{l}\text { Menguji hak akses } \\
\text { pengguna }\end{array}$ & $\begin{array}{l}\text { Mengisi user name, password } \\
\text { dengan tidak legkap lalu click } \\
\text { log-in }\end{array}$ & $\begin{array}{l}\text { Isi user name tanpa } \\
\text { password } \\
\text { Isi password tanpa } \\
\text { user name }\end{array}$ & $\begin{array}{l}\text { Sistem menolak akses } \\
\text { login } \\
\text { Sistem menolak akses } \\
\text { login }\end{array}$ & $\begin{array}{l}\text { Sesuai keinginan } \\
\text { pengguna } \\
\text { Sesuai keinginan } \\
\text { pengguna }\end{array}$ \\
\hline 2 & $\begin{array}{l}\text { Menguji fungsi } \\
\text { entry/edit/ delete data } \\
\text { dari setiap menu } \\
\text { setting data aplikasi }\end{array}$ & $\begin{array}{l}\text { Mengisi user name, password } \\
\text { yang memiliki hak akses } \\
\text { sistem dengan legkap dan } \\
\text { benar lalu click log-in. }\end{array}$ & $\begin{array}{l}\text { Masuk menu Data } \\
\text { dokter } \\
\text { Masuk menu Data } \\
\text { Pasien }\end{array}$ & $\begin{array}{l}\text { Dapat melakukan } \\
\text { entry/edit/ delete data } \\
\text { Dapat melakukan } \\
\text { entry/edit/delete data }\end{array}$ & $\begin{array}{l}\text { Sesuai keinginan } \\
\text { pengguna } \\
\text { Sesuai keinginan } \\
\text { pengguna }\end{array}$ \\
\hline & & $\begin{array}{l}\text { Click menu setting dan } \\
\text { masukan data master sistem }\end{array}$ & $\begin{array}{l}\text { Masuk menu Data } \\
\text { Obat }\end{array}$ & $\begin{array}{c}\text { Dapat melakukan } \\
\text { entry/edit/ delete data }\end{array}$ & $\begin{array}{l}\text { Sesuai keinginan } \\
\text { pengguna }\end{array}$ \\
\hline 3 & $\begin{array}{l}\text { Menguji laporan yang } \\
\text { dihasilkan sistem }\end{array}$ & $\begin{array}{l}\text { Mengisi user name, password } \\
\text { sesuai hak akses lalu click log- } \\
\text { in dan Click report }\end{array}$ & $\begin{array}{l}\text { Masuk ke menu } \\
\text { Report/ laporan }\end{array}$ & $\begin{array}{c}\text { Dapat menampilkan } \\
\text { mencetak laporan } \\
\text { sesuai yang diinginkan }\end{array}$ & $\begin{array}{c}\text { Sesuai keinginan } \\
\text { pengguna }\end{array}$ \\
\hline
\end{tabular}

\section{KESIMPULAN}

Berdasarkan hasil dari penelitian yang telah dilakukan peneliti mengambil beberapa kesimpulan, atara lain::

a. Sistem informasi pelayanan pasien yang dikembangkan telah membantu mempercepat proses pendataan rekam medis pasien, mengelola data obat, mengelola data dokter dan mengelola data laporan kegiatan yang dilakukan di klinik Jati Husada Tangerang.

b. Sistem informasii pelayanan pasien yang dikembangkan telah dapat menggantikan proses pekerjaan pendataan pasien, pendataan obat, pendataan dokter dan pelaporan yang sebelumnya dilakukan dengan konvensional (manual) menjadi terkomputerisasi.

c. Sistem informasi pelayanan pasien yang dikembangkan telah berjalan secara efektif dan efisien berdasarkan dari hasil pengujian black box sesuai yang diharapkan.

\section{DAFTAR PUSTAKA}

FITRIAWATI, N., HERDIANSAH, A. and GUNAWAN, A. (2019) 'Sistem Informasi Program Keluarga Harapan Studi Kasus Kecamatan Kosambi Tangerang', Jurnal Teknik Informatika (JIKA) Universitas Muhammadiyah Tangerang, 3(2), pp. 2126.

FU, L. and LING, L. (2014) 'The value of an integrated information system: A case of an out-patient clinic', Proceedings - 2nd International Conference on Enterprise
Systems, ES 2014, pp. 57-60. doi: 10.1109/ES.2014.31.

HERDIANSAH, A. (2020) 'Sistem Pendukung Keputusan Referensi Pemilihan Tujuan Jurusan teknik Di Perguruan', Jurnal MATRIK, 19(2), pp. 223-234.

HERDIANSAH, A., ROSDIANA and WULANDANI, F. (2019) 'Pengembangan Dashboard Kontrol Pengendalian Mutu Pada Bagian Printing Dan Emboss Pt. Megah Mas Prima', Jurnal Ilmiah Matrik, 21(3), pp. 266-278.

doi: 10.33557/jurnalmatrik.v21i3.731.

HERLIANA, A. (2014) 'Analisa dan Perancangan Sistem Informasi Data Pribadi dan Nilai Mahasiswa di Perguruan Tinggi (Studi Kasus Universitas Kebangsaan bandung)', Jurnal Informatika, I(2), pp. 82-92.

JOGIYANTO (2010) Analisis dan Desain Sistem Informasi. Yogyakarya: Andi Offset.

MEYER, H., FINGER, A. and HEUER, A. (2015) 'Building digital archives: Design decisions', 2015 4th International Symposium on Emerging Trends and Technologies in Libraries and Information Services (ETTLIS), pp. 59-64. doi: 10.1109/ETTLIS.2015.7048172.

PAN, L. et al. (2016) 'Design a Novel Electronic Medical Record System for Regional Clinics and Health Centers in China', IEEE International Conference on Computer and Communication, 2nd, pp. 38-41. 
PRESSMAN, R. (2015) Software Engineering: $A$ Practitioner's Approach. 7th editio. New York: The McGraw-Hill Company.

SUDARYONO (2015) Metodologi Riset di Bidang IT: Panduan Praktis, Teori dan Contoh Kasus. Ed.1. Yogyakarta: Andi Offset.

SUGIYONO (2013) Metode Penelitian Kombinasi (mixed Methodes). Ed.1. Bandung: Alfabeta - Bandung. 
Halaman ini sengaja dikosongkan 